\title{
Interaction among beta-endorphin, nitric oxide and prostaglandins during ovulation in rats
}

\author{
A. G. Faletti, C. Mohn, M. Farina, A. Lomniczi and V. Rettori \\ Centro de Estudios Farmacológicos y Botánicos (CEFYBO), Consejo Nacional de Investigaciones \\ Científicas y Técnicas (CONICET), Serrano 669, (1414), Buenos Aires, Argentina
}

\begin{abstract}
The aim of this study was to investigate the relationship between $\beta$-endorphin and nitric oxide (NO) during the ovulatory process in rats. Immature rats were treated with equine chorionic gonadotrophin-hCG to induce ovulation. An intrabursal injection of $\beta$-endorphin stimulated nitric oxide synthase (NOS) activity. This effect was completely reversed when naltrexone was co-injected with $\beta$-endorphin. The stimulatory action of $\beta$-endorphin on NOS activity was studied to determine whether it was exerted via prostaglandins. Treatment with prostaglandin $E_{2}\left(P G E_{2}\right)$ completely reversed the $\beta$-endorphin-induced stimulation of NOS activity. Moreover, intrabursal injection of meloxicam, an inhibitor of cyclooxygenase 2, increased
\end{abstract}

\section{Introduction}

Nitric oxide (NO) is considered to be an important intercellular messenger that controls many physiological processes (Moncada et al., 1991). NO is synthesized through the oxidation of L-arginine by nitric oxide synthase (NOS). NOS occurs in multiple isoforms: neuronal NOS (nNOS) and endothelial NOS (eNOS) are constitutive and calcium-calmodulin dependent (Bredt and Snyder, 1990; Pollock et al., 1991), whereas inducible NOS (iNOS) is calcium-calmodulin independent and cytokine inducible (Stuehr et al., 1991). The rat ovary synthesizes $\mathrm{NO}$ and it has been postulated that NO participates in follicular development, ovulation and luteal formation (Ellman et al., 1993; Ben-Shlomo et al., 1994; Shukovski and Tsafriri, 1994; Zackrisson et al., 1996).

Constitutive and inducible NOSs are present in ovarian cells (Van Voorhis et al., 1994) and NOS inhibitors have been shown to reduce the ovulation rate in vivo and in vitro (Shukovski and Tsafriri, 1994; Bonello et al., 1996). Increased concentrations of $\mathrm{NO}$ or $\mathrm{NO}$ releasing agents can inhibit steroidogenesis in granulosa and luteal cells in both rats and humans (Van Voorhis et al., 1994; Olson et al., 1996). Faletti et al. (1999a) reported that iNOS is the main isoform involved in the ovarian ovulatory process and that the NO produced as

Email: aliciafaletti@ciudad.com.ar
NOS activity, but this effect was not altered by co-injection with $\beta$-endorphin. The presence of both endothelial NOS (eNOS) and inducible NOS (iNOS) in the ovary at $10 \mathrm{~h}$ after hCG treatment was studied by western blot analysis. Local administration of $\beta$-endorphin inhibited the expression of eNOS protein, whereas expression of iNOS protein was not detectable. Ovarian $\beta$-endorphin content was diminished at $10 \mathrm{~h}$ after hCG injection. Treatment with prostaglandin synthesis inhibitors in vivo augmented the ovarian $\beta$-endorphin content. In conclusion, these results indicate that $\beta$-endorphin stimulates the activity of ovarian NOS indirectly by inhibiting prostaglandin production. a result stimulates the synthesis of prostaglandins that enhance the process of follicle rupture.

$\beta$-Endorphin, a pro-opiomelanocortin (POMC)derived peptide, has been found in the female reproductive systems of several species. This endogenous opioid is present in sheep (Lim et al., 1983) and human (Aleem et al., 1986) ovaries, in luteal cells of mice (Shaha et al., 1984) and in granulosa and interstitial cells of rodents (Lolait et al., 1985, 1986). mRNA for POMC is also found in the ovary and uterus of mice, monkeys, hamsters (Chen et al., 1986; Jin et al., 1988), rats (Sanders et al., 1990) and fertile women (Galinelli et al., 1995). Previous studies have shown that $\beta$ endorphin may affect ovarian function both directly and indirectly, by modulating $\mathrm{LH}$ secretion (Leadem and Kalra, 1985; Gregoraszczuk and Slomczynska, 1998; Kaminski et al., 2000). $\beta$-Endorphin synthesis occurs in ovarian follicles, but the relatively low concentrations found in reproductive tissues indicate that it exerts autocrine or paracrine effects in the ovary (Lim et al., 1983; Lolait et al., 1985; Hamada et al., 1995). Faletti et al. $(1995,1999 \mathrm{~b})$ reported that the ovulation rate and the ovarian production of preovulatory prostaglandins were inhibited by $\beta$-endorphin and stimulated by naltrexone. Because $\mathrm{NO}$ stimulates the production of prostaglandins, the aim of the present study was to investigate the relationship between $\beta$-endorphin and the NO-NOS system during the ovulatory process in rats. 


\section{Materials and Methods}

\section{Animals}

The animal model used was the same as that described by Faletti et al. (1999a). Briefly, immature female Sprague-Dawley rats were housed in a light (06:0020:00 h) and temperature $\left(22^{\circ} \mathrm{C}\right)$ controlled room, and had free access to laboratory chow and water. At 08:00 h, immature rats of 28-30 days of age were injected i.p. with 15 iu equine chorionic gonadotrophin (eCG) (in $0.15 \mathrm{ml}$ saline) to induce the growth of the first generation of preovulatory follicles. After $48 \mathrm{~h}$, the rats were injected i.p. with 15 iu hCG (in $0.15 \mathrm{ml}$ saline) to induce ovulation, which usually occurs within 12 $14 \mathrm{~h}$ after hCG administration in this rat colony. The rats were killed by cervical dislocation at $0,4,10$ or $12 \mathrm{~h}$ after hCG injection to measure the ovarian $\beta$ endorphin content. Previous studies have shown that gonadotrophin administration increases ovarian NOS activity and prostaglandin content, and that these increases reach a peak at $10 \mathrm{~h}$ after hCG administration (Faletti et al., 1995, 1999a). Therefore, this time was chosen as the time before ovulation when NOS activity and prostaglandin content are greatest. Thus, $8 \mathrm{~h}$ after hCG treatment $(16: 00 \mathrm{~h})$, the rats were anaesthetized with ether and the compounds to be tested were injected in $50 \mu \mathrm{l}$ saline into each ovary as described by Shukovski and Tsafriri (1994). Briefly, the rats were anaesthetized with ether and each ovary was exposed via a small lumbosacral incision. A 30-gauge needle was introduced into the ovarian bursa via the adjoining fat pad. The local injection was assured by observing the needle tip through the bursa wall and confirmed by the swelling of the bursa. After the injection, the ovary was placed back into the abdominal cavity, and the skin was sutured. After $2 \mathrm{~h}$, these animals were killed by cervical dislocation. The ovaries were removed immediately, frozen on dry ice and stored at $-70^{\circ} \mathrm{C}$ until measurements of NOS activity, western blot analysis or determination of $\beta$-endorphin content. The number of animals per group was between five and six per experiment. The experiments were repeated at least twice. All procedures involving animals were carried out according to the NIH guide for the care and use of laboratory animals, and were approved by the Animal Care and Use Committee of Centro de Estudios Farmacológicos y Botánicos (CEFYBO-CONICET).

\section{Drugs and chemicals}

Hepes, eCG, hCG, prostaglandin $\mathrm{E}_{2}\left(\mathrm{PGE}_{2}\right), \mathrm{NADPH}$, $N^{G}$-nitro-L-arginine methyl ester and $N^{G}$-nitro-D-arginine methyl ester (L-NAME and L-NAME), $N^{G}$-methylL-arginine and $N^{G}$-methyl-D-arginine (L-NMMA and D-NMMA), L-citrulline, L-valine, indomethacin and dithiothreitol were purchased from Sigma Chemicals Co. (St Louis, MO). Meloxicam was obtained from Boehringer Ingelheim, and $\left.{ }^{3} \mathrm{H}\right] \mathrm{PGE}_{2}\left(181 \mathrm{Ci} \mathrm{mmol}^{-1}\right)$ and $\left[{ }^{14} \mathrm{C}\right]$ arginine $\left(348 \mathrm{mCi} \mathrm{mmol}^{-1}\right)$ from Amersham Pharmacia Biotech (Piscataway, NJ). $\beta$-Endorphin for iodination and standards was purchased from Peninsula Laboratories, and Dowex AG50W-X8 resin was obtained from Bio-Rad Laboratories (Hercules, CA). The western blot analysis reagents were obtained from Sigma and BioRad Laboratories.

\section{Nitric oxide activity assay}

NOS activity was measured using the conversion of L- $\left[{ }^{14} \mathrm{C}\right]$ arginine into L- $\left[{ }^{14} \mathrm{C}\right]$ citrulline assay, according to Bredt and Snyder (1989). On the day when the assay was carried out, both ovaries from each animal were thawed, trimmed of visible fat, weighed and homogenized using a tissue homogenizer with Teflon pestle (Eberbach) in $500 \mu \mathrm{l}$ buffer Hepes, pH 7.4, containing $0.45 \mathrm{mmol}$ $\mathrm{CaCl}_{2} \mathrm{I}^{-1}$ and $1.0 \mathrm{mmol}$ dithiothreitol $\mathrm{I}^{-1}$. The homogenates were incubated at $37^{\circ} \mathrm{C}$ in the presence of $\left[{ }^{14} \mathrm{C}\right]$ arginine $(0.2 \mu \mathrm{Ci})$ and $1 \mathrm{mmol} \mathrm{NADPH} \mathrm{I}^{-1}$ in an atmosphere of $5 \% \mathrm{CO}_{2}$ in $95 \% \mathrm{O}_{2}$. Valine $(25 \mathrm{mmol}$ $\mathrm{I}^{-1}$ ), which inhibits the conversion of L-arginine into L-citrulline by arginases, was included in the reaction mixture to increase the specificity of the assay. After $15 \mathrm{~min}$ of incubation, samples were centrifuged for $10 \mathrm{~min}$ at $7800 \mathrm{~g}$ and the supernatant was applied to a $1 \mathrm{ml}$ DOWEX AG50W-X8 column $\left(\mathrm{Na}^{+}\right.$form) equilibrated with $20 \mathrm{mmol}^{-}$Hepes $\mathrm{I}^{-1}$, $\mathrm{pH}$ 7.4, and $\left[{ }^{14} \mathrm{C}\right]$ citrulline was eluted with $3 \mathrm{ml}$ water. The radioactivity was measured by liquid scintillation counting. Because the formation of L-citrulline is stoichiometric with the formation of $\mathrm{NO}$, it was assumed that an equal amount of $\mathrm{NO}$ was formed. The enzyme activity was expressed in pmol NO per g wet mass per min. Intraand interassay coefficients of variation were $<10 \%$.

\section{Western blot analysis}

Soluble tissue extracts were prepared as described by Farina et al. (2001). Briefly, frozen ovaries from each animal were homogenized in $20 \mathrm{mmol}$ ice-cold Tris- $\mathrm{HCl}$ buffer $\mathrm{I}^{-1}, \mathrm{pH} 7.4$, containing $0.25 \mathrm{mmol}$ sucrose $\mathrm{I}^{-1}, 1.0 \mathrm{mmol}^{\mathrm{EDTA}} \mathrm{I}^{-1}, 10.0 \mu \mathrm{g}$ aprotinin $\mathrm{ml}^{-1}$, $10.0 \mu \mathrm{g}$ leupeptin $\mathrm{ml}^{-1}, 100.0 \mu \mathrm{g}$ phenylmethylsulphonyl fluoride $\mathrm{ml}^{-1}$ and $10.0 \mu \mathrm{g}$ trypsin inhibitors $\mathrm{ml}^{-1}$. The homogenates were sonicated and then centrifuged at $7800 \mathrm{~g}$ for $10 \mathrm{~min}$ at $4{ }^{\circ} \mathrm{C}$. The protein concentrations in the supernatants were determined by the Bradford method using BSA as the standard. Homogenates were heated for $4 \mathrm{~min}$ to $100^{\circ} \mathrm{C}$ in buffer containing $0.3 \%$ $(\mathrm{w} / \mathrm{v})$ bromophenol blue, $55 \mu \mathrm{l}$ distilled water and $25 \mu \mathrm{l} \beta$-mercaptoethanol. Equal amounts of protein $(100 \mu \mathrm{g})$ were loaded on to $4 \%(\mathrm{w} / \mathrm{v}) \quad 0.125 \mathrm{mmol}$ Tris- $\mathrm{HCl} \mathrm{I}^{-1}, \mathrm{pH} 6.8$, stacking polyacrylamide gel, followed by a $7.5 \% \quad(\mathrm{w} / \mathrm{v}) \quad 0.375 \mathrm{mmol}$ Tris- $\mathrm{HCl}$ $\mathrm{I}^{-1}, \mathrm{pH}$ 8.8, separating polyacrylamide gel. After 
electrophoresis, the proteins were transferred on to nitrocellulose membranes (Pharmacia Biotech, Uppsala) and maintained overnight in a cold chamber using a BioRad transblot apparatus. Membranes were first blocked for $1 \mathrm{~h}$ at room temperature in Tris- $\mathrm{HCl}$ : saline $(50 \mathrm{mmol}$ Tris- $\mathrm{HCl} \mathrm{I}{ }^{-1}: 500 \mathrm{mmol} \mathrm{NaCl} \mathrm{I}{ }^{-1}, \mathrm{pH}$ 7.5) containing $5 \%(\mathrm{w} / \mathrm{v})$ milk powder, and then incubated overnight at $4{ }^{\circ} \mathrm{C}$ with antibodies raised in rabbit against eNOS and iNOS (Transduction Laboratories, Lexington, KY). The final dilution of both antibodies was $1: 1000$. The membranes were washed three times for $10 \mathrm{~min}$ each in Tris- $\mathrm{HCl}$ : saline containing $0.1 \%(\mathrm{v} / \mathrm{v})$ Tween-20, $\mathrm{pH}$ 7.5. The membranes were then incubated for $1 \mathrm{~h}$ at room temperature with alkaline phosphatase-conjugated antirabbit IgG as the secondary antibody and the colour developed with 5-bromo-4-chloro-3-indolyl-phosphate toluidine salt and nitroblue tetrazolium. Molecular mass standards were run under the same conditions to identify the protein bands. Blots were scanned using a scanning UMAX Astra 12205 and densitometry was performed using a Dekmate III Sigma Gel software package (Jandel Scientific software). Positive controls for iNOS included homogenates of lipopolysaccharideactivated RAW 264.7 macrophages.

\section{Ovarian content of $\beta$-endorphin}

The ovaries from each rat treated with eCG-hCG were removed at $0,4,10$ or $12 \mathrm{~h}$ after hCG administration, trimmed of visible fat and the oviduct was weighed and homogenized using a tissue homogenizer with Teflon pestle (Eberbach) in $500 \mu \mathrm{l}$ cold PBS, pH 7.4, containing a mixture of protease inhibitors $(2 \mathrm{mmol}$ EDTA $\mathrm{I}^{-1}, 20 \mathrm{mmol} N$-ethylmaleimide $\mathrm{I}^{-1}, 1 \mathrm{mmol}$ phenylsulphonylfluoride $\mathrm{I}^{-1}$ and $1 \mathrm{mmol}$ dithiothreitol $I^{-1}$ ). The homogenates were heated for $10 \mathrm{~min}$ at $100^{\circ} \mathrm{C}$ and centrifuged for $30 \mathrm{~min}$ at $10000 \mathrm{~g}$ at $4^{\circ} \mathrm{C}$. The supernatants were purified using Sep-Pak $\mathrm{C}_{18}$ cartridges, lyophilized and reconstituted before being assayed. $\beta$-Endorphin was quantified by radioimmunoassay as in previous studies (Faletti et al., 1999b; Lomniczi et al., 2000) using a highly specific antiserum kindly provided by G. Chrousos (National Institute of Child Health and Human Development, Bethesda, MD). The sensitivity of the assay was $20 \mathrm{pg}$ per tube and the curve was linear up to $1000 \mathrm{pg} \beta$-endorphin. The antibody crossreacted on an equimolar basis with rat $\beta$-endorphin and its immediate precursor, $\beta$-lipotropin. Thus, the activity measured in this assay represents the combined concentrations of $\beta$-endorphin and $\beta$-lipotropin, and is referred to as $\beta$-endorphin-like immunoreactivity. Methionine-enkephalin, $\alpha$-endorphin and other opioid peptides did not crossreact $(<0.1 \%$ crossreactivity). Human $\beta$-endorphin (1-27 fraction) from Peninsula Laboratories (San Carlos, CA) was used for iodination by chloramine $T$ method, because this fraction has two tyrosine residues. Rat $\beta$-endorphin has only one tyrosine residue and the iodination of this peptide is very poor. Rat $\beta$-endorphin was used for standards and serial dilutions of the samples showed parallelism with the standards curve. The intra- and interassays coefficients of variation were 8.5 and $12.1 \%$, respectively.

\section{Statistical analysis}

All data are expressed as means \pm SEM. Comparisons between groups were performed using a one-way ANOVA and Student-Newman-Keuls' multiple comparison test. The difference between the saline group and $\beta$-endorphin-treated group in western blot analysis was analysed using Student's $t$ test. Differences between groups were considered significant when $P<0.05$.

\section{Results}

\section{Activity of ovarian nitric oxide synthase}

Rats were injected intrabursally with saline, $\beta$ endorphin (2-200 ng) or $\beta$-endorphin (200 ng) plus naltrexone $(200 \mathrm{ng})$ at $16: 00 \mathrm{~h}(8 \mathrm{~h}$ after $\mathrm{hCG})$ and ovarian NOS activity was measured $2 \mathrm{~h}$ later $(10 \mathrm{~h}$ after $\mathrm{hCG}$ ) to determine whether high concentrations of $\beta$-endorphin alter the ovarian total NOS activity during the ovulatory process in rats. All doses of $\beta$ endorphin significantly increased ovarian NOS activity in comparison with the saline control (Fig. 1). The intrabursal injection of saline solution did not alter NOS activity in comparison with untreated animals. The effect of $\beta$-endorphin (200 ng) was completely reversed by co-injection of $\beta$-endorphin with naltrexone (200 ng).

Rats were injected intrabursally with meloxicam $(0.5$ and $5.0 \mu \mathrm{g})$, an inhibitor of cyclooxygenase 2, or $\mathrm{PGE}_{2}(0.5$ and $5.0 \mu \mathrm{g}), 8 \mathrm{~h}$ after hCG treatment to determine whether ovarian prostaglandins modulate the ovarian NO-NOS system, and ovarian NOS activity was measured $2 \mathrm{~h}$ later. Both doses of meloxicam induced a significant increase in NOS activity and $\mathrm{PGE}_{2}$, at the doses used, significantly reduced NOS activity (Fig. 2).

As $\beta$-endorphin exerts inhibitory affects on preovulatory prostaglandin production (Faletti et al., 1995, 1997) and increases NOS activity (Fig. 1), it was of interest to determine whether $\beta$-endorphin would potentiate the stimulatory effect of meloxicam on NOS activity. The meloxicam-induced stimulation of ovarian NOS activity was not affected by co-injection of meloxicam $(5 \mu \mathrm{g})$ with $\beta$-endorphin (200 ng), but $\mathrm{PGE}_{2}(5 \mu \mathrm{g})$ co-injected with $\beta$-endorphin (200 ng) reversed the $\beta$-endorphininduced stimulation of NOS activity (Fig. 3).

\section{Immunodetection of nitric oxide synthase proteins}

Western blot analysis was used to determine whether changes in eNOS and iNOS correlated with changes in 


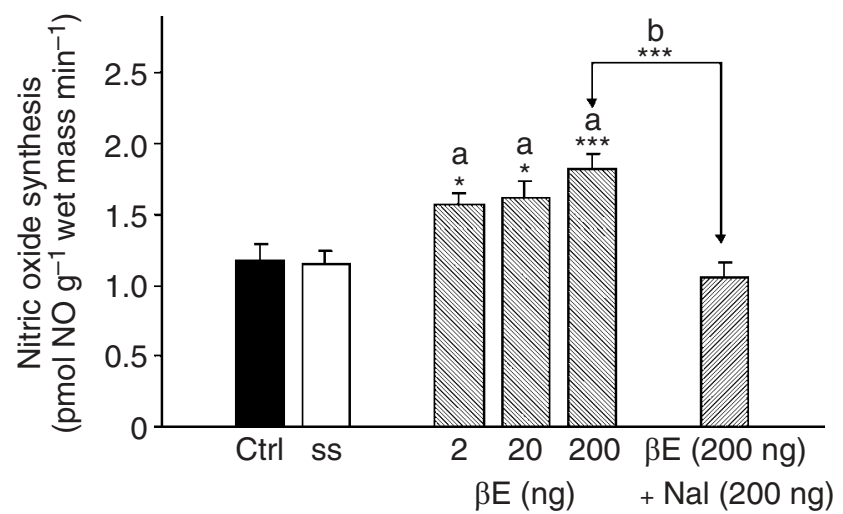

Fig. 1. Effect of intrabursal injection with $\beta$-endorphin $(\beta E)$ (2-200 ng) or naltrexone (Nal) (200 ng) on ovarian nitric oxide synthase (NOS) activity in immature rats treated with equine chorionic gonadotrophin-hCG. The intrabursal injection was administered at $16: 00 \mathrm{~h}(8 \mathrm{~h}$ after $\mathrm{hCG}$ treatment) and the activity of NOS was measured $2 \mathrm{~h}$ later $(18: 00 \mathrm{~h})$. This activity was measured by the conversion assay of $\left[{ }^{14} \mathrm{C}\right]$ arginine into $\left[{ }^{14} \mathrm{C}\right]$ citrulline in ovarian homogenates and was expressed as pmol of NO per min per g wet mass. Columns represent ovaries without intrabursal injection (control, Ctrl), ovaries treated with saline solution (ss) or $\beta E$ or $\beta E$ plus Nal via intrabursal injection. Each bar represents the mean \pm SEM for eight to ten animals per group. ${ }^{*} P<0.05,{ }^{* * *} P<0.001 ;$ a $\beta$ E versus ss; ${ }^{\mathrm{b}} \beta$ E plus Nal versus $\beta \mathrm{E} 200$ ng (ANOVA and Student-Newman-Keuls multiple comparison test).

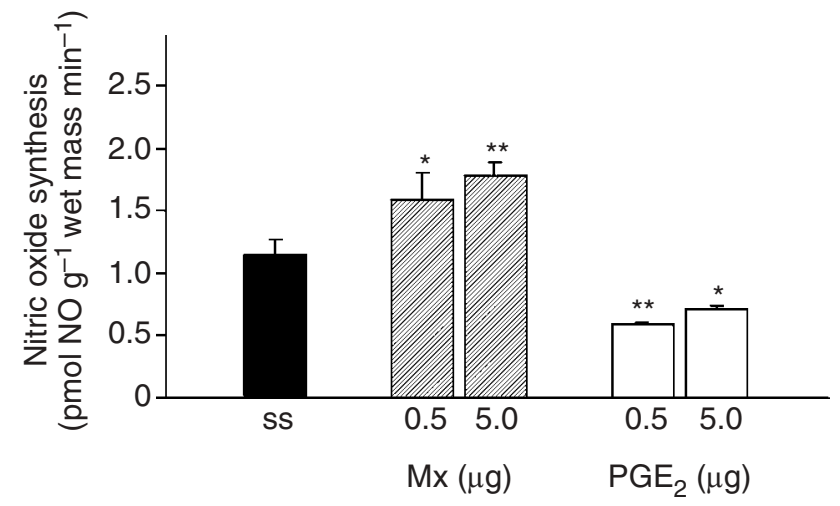

Fig. 2. Effect of intrabursal injection with meloxicam (Mx) $(0.5$ and $5.0 \mu \mathrm{g}$ ), an inhibitor of cyclooxygenase II, or prostaglandin $E_{2}\left(P_{E_{2}}\right)(0.5$ and $5.0 \mu \mathrm{g})$ on ovarian nitric oxide synthase (NOS) activity in immature rats treated with equine chorionic gonadotrophin-hCG. The intrabursal injection was administered at 16:00 $\mathrm{h}$ ( $8 \mathrm{~h}$ after hCG treatment) and the activity of NOS was measured $2 \mathrm{~h}$ later $(18: 00 \mathrm{~h})$. This activity was measured by the conversion assay of $\left[{ }^{14} \mathrm{C}\right]$ arginine into $\left[{ }^{14} \mathrm{C}\right]$ citrulline in ovarian homogenates and was expressed as pmol of $\mathrm{NO}$ per min per $\mathrm{g}$ wet mass. Columns represent ovaries treated with saline solution (ss), meloxicam (Mx) or $\mathrm{PGE}_{2}$ via intrabursal injection. Each bar represents the mean \pm SEM for eight to ten animals per group. ${ }^{*} P<0.05,{ }^{* *} P<0.01$; treated versus ss (ANOVA and StudentNewman-Keuls multiple comparison test).

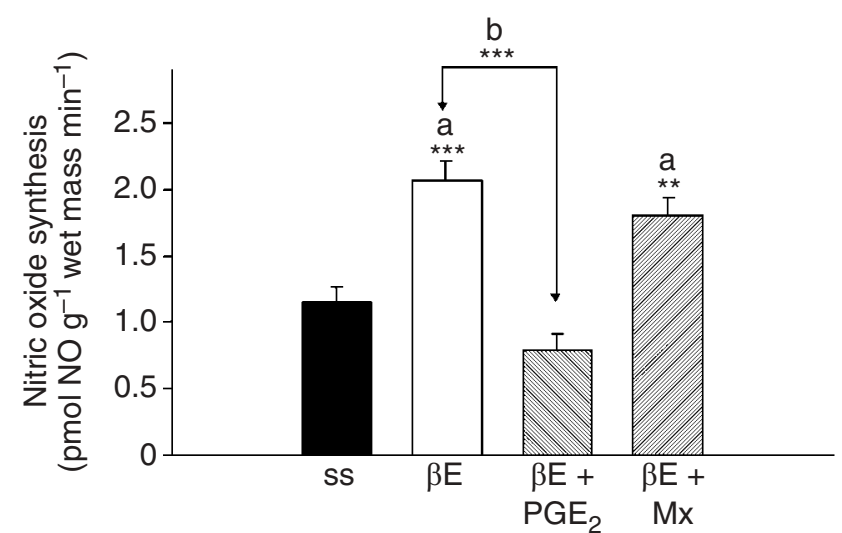

Fig. 3. Effect of intrabursal injection with $\beta$-endorphin $(\beta E)$ (200 ng), $\beta E(200 \mathrm{ng})$ plus prostaglandin $\mathrm{E}_{2}\left(\mathrm{PGE}_{2}\right)(5 \mu \mathrm{g})$ or $\beta E$ (200 ng) plus meloxicam (Mx) $(5 \mu \mathrm{g})$ on ovarian nitric oxide synthase (NOS) activity in immature rats treated with equine chorionic gonadotrophin-hCG. The intrabursal injection was administered at $16: 00 \mathrm{~h}$ ( $8 \mathrm{~h}$ after hCG treatment) and the activity of NOS was measured $2 \mathrm{~h}$ later (18:00 h). This activity was measured by the conversion assay of $\left[{ }^{14} \mathrm{C}\right]$ arginine into $\left[{ }^{14} \mathrm{C}\right]$ citrulline in ovarian homogenates and was expressed as pmol of $\mathrm{NO}$ per min per g wet mass. Columns represent ovaries treated with saline solution (ss), $\beta E, \beta E$ plus $\mathrm{PGE}_{2}$ or $\beta E$ plus $\mathrm{Mx}$ via intrabursal injection. Each bar represents the mean \pm SEM for eight to ten animals per group. ${ }^{* *} P<0.01,{ }^{* * *} P<0.001$; ${ }^{\text {a }}$ treated versus ss; ${ }^{b} \beta E$ plus $\mathrm{PGE}_{2}$ versus $\beta E$ (ANOVA and Student-NewmanKeuls multiple comparison test).

total NOS activity. The antibody to eNOS reacted with the appropriate band corresponding to the $140 \mathrm{kDa}$ protein from the membrane fraction of human endothelial cells (data not shown). A protein band at $140 \mathrm{kDa}$ corresponding to the size of eNOS was expressed at detectable amounts in all ovaries at $10 \mathrm{~h}$ after hCG treatment from immature rats primed with eCG and treated with saline (lanes 1 and 2) or $\beta$ endorphin (200 ng) (lanes 3-5) $2 \mathrm{~h}$ previously (Fig. 4a). The intrabursal injection of saline solution did not alter the eNOS expression in comparison with untreated ovaries (data not shown). Densitometric analysis revealed that the expression of eNOS protein was high in ovaries after intrabursal injection with saline at $10 \mathrm{~h}$ after hCG administration, but that this expression was reduced in ovaries from rats that received an intrabursal injection of $\beta$-endorphin $(P<0.05)$ (Fig. 4b). The antibody to iNOS reacted with the band corresponding to $130 \mathrm{kDa}$ in positive control (homogenates of LPS-activated mouse macrophages), but this expression was not detectable in ovaries obtained at $10 \mathrm{~h}$ after hCG administration from immature rats primed with eCG-hCG and treated with saline or $\beta$-endorphin (data not shown). When this assay was repeated using a chemiluminescence detection kit (Amersham Pharmacia Biotech) with antirabbit IgG horseradish peroxidase-conjugated anti-rabbit 
(a)
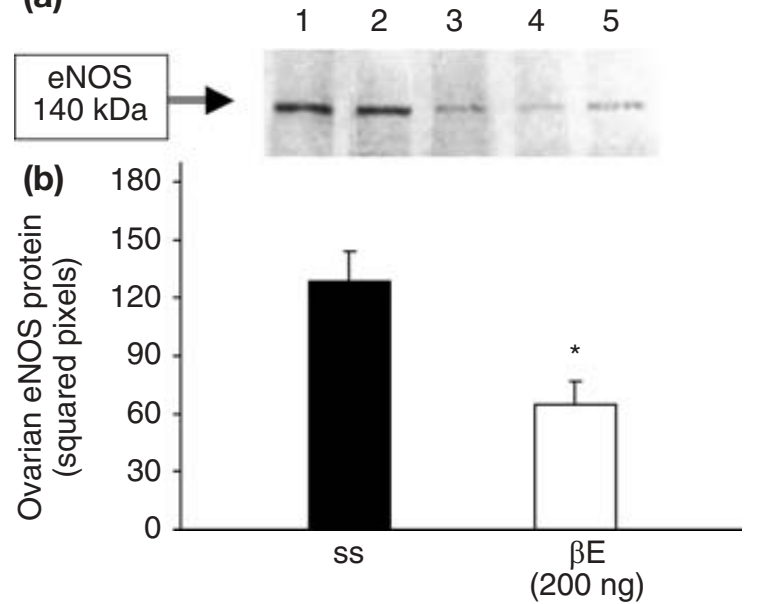

Fig. 4. Effect of intrabursal injection with $\beta$-endorphin $(\beta E)$ on ovarian endothelial nitric oxide synthase (eNOS) protein. (a) Expression of ovarian eNOS protein by western blot analysis at $10 \mathrm{~h}$ after hCG from immature rats primed with equine chorionic gonadotrophin-hCG. Rats received an intrabursal injection of either saline solution (ss) (lanes 1 and 2) or $200 \mathrm{ng} \beta \mathrm{E}$ (lanes 3-5) at $8 \mathrm{~h}$ after hCG treatment. (b) Quantitative analysis of ovarian eNOS expression after treatment. Data points represent the mean $\pm S E M$; $n=5$ animals per group. ${ }^{*} P<0.05$ (Student's $t$ test).

IgG (Sigma), the expression of iNOS was undetectable (data not shown).

\section{Ovarian content of $\beta$-endorphin}

$\beta$-Endorphin-like immunoreactivity was measured in ovaries of eCG-hCG-treated immature rats to determine ovarian $\beta$-endorphin content during the ovulatory process in rats. The ovarian $\beta$-endorphin-like immunoreactivity at different times after hCG injection is shown (Fig. 5). At $10 \mathrm{~h}$, the production of $\beta$-endorphinlike immunoreactivity was significantly lower than that observed at 0 and $4 \mathrm{~h}$ after injection $(P<0.001)$.

Inhibitors of prostaglandins synthesis (indomethacin, meloxicam) and inhibitors of NO production (L-NAME, L-NMMA) were injected intrabursally at $8 \mathrm{~h}$ after hCG treatment and the ovarian $\beta$-endorphin-like immunoreactivity was measured $2 \mathrm{~h}$ later to study whether the reduction in ovarian $\beta$-endorphin concentrations during the ovulatory process was related to the increase in prostaglandins and $\mathrm{NO}$ production. Ovarian $\beta$ endorphin-like immunoreactivity at $0 \mathrm{~h}$ in control ovaries and at $10 \mathrm{~h}$ after hCG administration in treated ovaries is shown (Fig. 6). Both treatments, indomethacin (10 $\mu \mathrm{g})$ or meloxicam $(10 \mu \mathrm{g})$, induced a significant increase in ovarian $\beta$-endorphin-like immunoreactivity $(P<0.01)$, but immunoreactivity was lower than that before hCG administration. The hCG-induced inhibition of ovarian $\beta$-endorphin-liker immunoreactivity was unaffected by

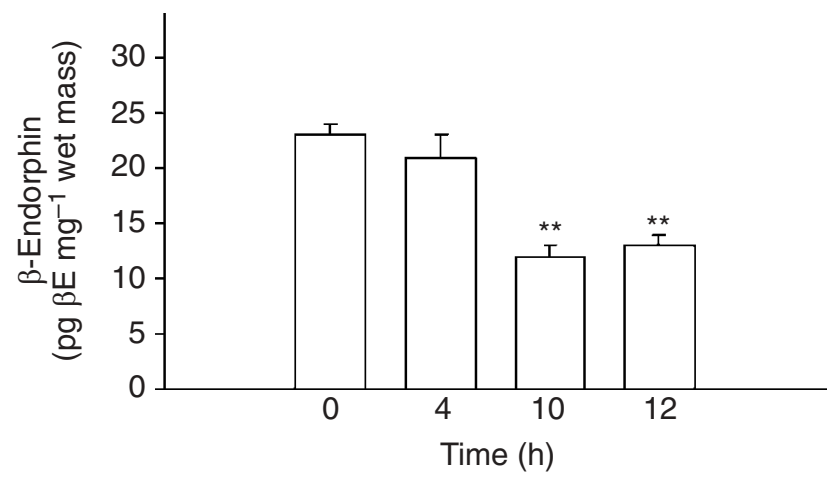

Fig. 5. Content of ovarian $\beta$-endorphin-like immunoreactivity from prepuberal rats treated with equine chorionic gonadotrophin-hCG at $0,4,10$ and $12 \mathrm{~h}$ after hCG treatment. $\beta$-Endorphin $(\beta \mathrm{E})$ was quantified by radioimmunoassay in ovarian homogenates purified and was expressed as pg $\beta$ E-like immunoreactivity per mg wet mass. Each bar represents the mean \pm SEM for eight to ten animals per group. ${ }^{* *} P<0.001$ versus $0 \mathrm{~h}$ (ANOVA and Student-NewmanKeuls multiple comparison test).

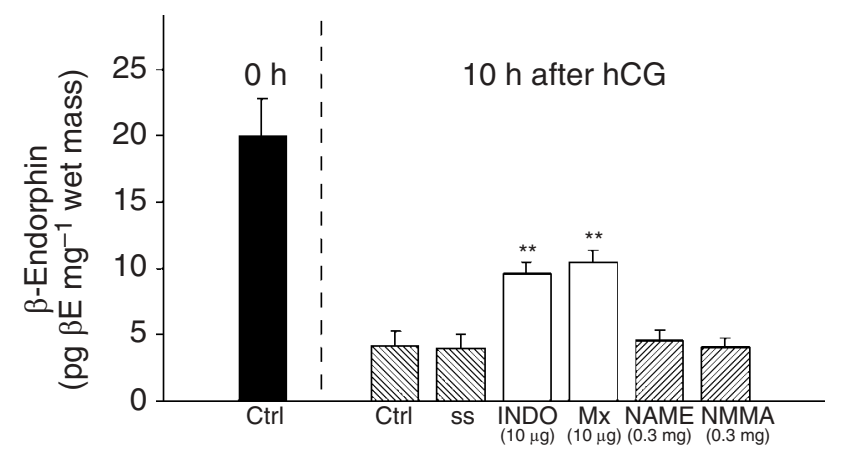

Fig. 6. Effect of intrabursal injection (at $8 \mathrm{~h}$ after hCG treatment) with indomethacin (INDO) $(10 \mu \mathrm{g})$ or meloxicam (Mx) $(10 \mu \mathrm{g})$, two inhibitors of prostaglandin synthesis, L-NAME or L-NMMA $(0.3 \mathrm{mg})$, two competitive inhibitors of nitric oxide synthase (NOS), on ovarian $\beta$-endorphin $(\beta \mathrm{E})$ production in immature rats treated with equine chorionic gonadotrophin-hCG. $\beta E$ was quantified by radioimmunoassay in purified ovarian homogenates and was expressed as pg $\beta E$-like immunoreactivity per mg wet mass. The left of the dashed line shows the content of $\beta E$-like immunoreactivity at the moment of hCG injection $(0 \mathrm{~h})$. The right of the dashed line shows the content of $\beta \mathrm{E}$-like immunoreactivity, at $10 \mathrm{~h}$ after hCG, in ovaries without intrabursal injection $(\mathrm{Ctrl})$, in ovaries treated with saline solution (ss) or different inhibitors via intrabursal injection. Each bar represents the mean \pm SEM for eight to ten animals per group. ${ }^{* *} P<0.01$ treated versus ss at $10 \mathrm{~h}$ after hCG (ANOVA and Student-Newman-Keuls multiple comparison test).

treatment with NOS inhibitors $(0.3 \mathrm{mg}$ L-NAME or $0.3 \mathrm{mg}$ L-NMMA).

\section{Discussion}

NOS activity has been detected in male and female reproductive organs (Burnett et al., 1995; Suburu et al., 1995). In a previous study, it was shown that gonadotrophin administration resulted in an increase in 
NOS activity and that this increase reached a peak at $10 \mathrm{~h}$ after hCG treatment (Faletti et al., 1999a). The present study investigated the action of $\beta$-endorphin on ovarian NOS activity during the ovulatory process. $\beta$-Endorphin was injected into each bursa $2 \mathrm{~h}$ before NOS activity was highest. The results of the present study indicate the $\beta$-endorphin stimulates ovarian NOS activity. This effect is mediated largely by $\mu$-receptors, the major receptor activated by $\beta$-endorphin, as naltrexone, a relatively specific $\mu$-receptor antagonist, inhibited the action of $\beta$-endorphin on NOS activity. Recent studies indicate that $\mathrm{NO}$ is involved directly in the ovulatory process (Shukovski and Tsafriri, 1994; Bonello et al., 1996; Jablonka-Shariff and Olson, 1998; Drazen et al., 1999; Jablonka-Shariff et al., 1999; Mitsube et al., 1999; Nakamura et al., 1999). Faletti et al. (1999a) reported that $\mathrm{NO}$ is involved in ovulation in the rats by stimulating the production of prostaglandins. The ovarian concentration of prostaglandins increases after the $\mathrm{LH}$ surge or in response to gonadotrophin stimulation (Bauminger and Lidner, 1975; Brown and Poyser, 1984; Faletti et al., 1995). Recent studies have demonstrated that endogenous and exogenous stimulators of $\mathrm{NO}$ production increase the synthesis of prostaglandins by direct activation of cyclooxygenase (Salvemini et al., 1993; Yamauchi et al., 1997). Faletti et al. (1999a) demonstrated that two competitive inhibitors of NOS activity, L-NAME and L-NMMA, inhibited the ovarian production of prostaglandins in vivo and in vitro and that a NO donor, SIN-1 (3-morpholinosydnoniminehidrochloride), was able to increase the synthesis of prostaglandins in vitro. Other studies using rat uterus also demonstrated the relationship between $\mathrm{NO}$ and prostaglandins during implantation, pregnancy and labour (Dong and Yallampalli, 1996; Farina et al., 2000). The present study investigated whether ovarian prostaglandins were able to regulate $\mathrm{NO}$ production during the ovulatory process and found that intrabursal administration of $\mathrm{PGE}_{2}$ inhibited ovarian NOS activity and meloxicam, an inhibitor of COX-2, produced an important increase in NOS activity. These results indicate that during the ovulatory process the increase in ovarian NOS activity results in an increase in $\mathrm{NO}$, which stimulates prostaglandin production and enhances the inflammatory process, facilitating follicle rupture. However, high concentrations of prostaglandins, in turn, exert a negative downregulation on ovarian NOS activity to regulate the production of NO. Faletti et al. (1995) demonstrated that $\beta$-endorphin inhibits the ovulatory process, at least in part, by inhibiting the production of ovarian prostaglandins. The production of prostaglandins in vivo and in vitro by preovulatory ovaries collected from rats treated with eCG-hCG was inhibited by $\beta$-endorphin. Moreover, the ovarian preovulatory production of prostaglandins from adult rats was diminished by intrabursal injection of $\beta$-endorphin and was increased by naltrexone (Faletti et al., 1997).
The mechanisms of action of $\beta$-endorphin on NOS activity were investigated to ascertain whether this action was exerted via prostaglandins. Treatment with $\mathrm{PGE}_{2}$ in vivo completely reversed the $\beta$-endorphin-induced stimulation of NOS activity. Moreover, the stimulatory effect of meloxicam or $\beta$-endorphin on NOS activity was not additive. Therefore, all of these results indicate that $\beta$-endorphin appears to stimulate the activity of ovarian NOS indirectly, by inhibiting prostaglandin production.

The expression of two different isoforms of NOS, iNOS and eNOS, and their regulation by gonadotrophins has been examined extensively in the rat ovary (Van Voorhis et al., 1995; Zackrisson et al., 1996; JablonkaShariff and Olson, 1997). Nevertheless, the contribution of each isoform to ovulation is still not clear. JablonkaShariff and Olson (1997) used immunohistochemistry and western blot analysis to demonstrate that eNOS and iNOS proteins, but not nNOS, are expressed in the rat ovary and are regulated by gonadotrophins. These workers found that the expression of eNOS increases after eCG-induced follicular development and continues to increase after an ovulatory dose of hCG to reach its maximum expression in the corpus luteum. eNOS is commonly described as a constitutively expressed protein, but the expression of this protein can be altered by various factors. In the present study, the expression of ovarian eNOS was inhibited by local administration of $\beta$-endorphin. In previous studies $\beta$-endorphin was found to inhibit the uptake of $\mathrm{Ca}^{2+}$ in isolated strips of rat uterus (Faletti et al., 1992) and decidual cells (Nandhra and Carson, 2000); therefore, the activity of NOS would be expected to be inhibited. However, injection with $\beta$-endorphin into the ovaries of immature rats primed with eCG-hCG resulted in an increase in the total activity of ovarian NOS at $10 \mathrm{~h}$ after hCG treatment. On the basis of these results, it was speculated that $\beta$-endorphin is acting indirectly on NOS activity via inhibition of prostaglandin production. This activation of NOS could generate excessive amounts of $\mathrm{NO}$ which could reduce protein synthesis in a negative feedback mechanism.

Jablonka-Shariff and Olson (1997) have found that during eCG-induced follicular development, iNOS protein content remained relatively constant, but an ovulatory dose of hCG (10 iu) produced an increase in iNOS protein that reached its maximum in the late corpus luteum. In contrast, Zackrisson et al. (1996) found that iNOS protein was barely detectable during follicular development and the ovulatory process. Other workers have reported maximal expression of iNOS mRNA in unstimulated ovaries and that this was reduced after hCG injection (Van Voorhis et al., 1995). In the present study, iNOS was not detected in ovaries obtained at $10 \mathrm{~h}$ after hCG from immature rats primed with eCG. It is possible that the iNOS protein contents were so low that the sensitivity of the method used was 
not sufficient to detect this protein in our biological model.

$\beta$-Endorphin-like immunoreactivity in the ovaries of eCG-hCG treated immature rats was measured to study the production of ovarian $\beta$-endorphin during ovulation. The $\beta$-endorphin-like immunoreactivity diminished at $10 \mathrm{~h}$ after hCG treatment and remained at these values until ovulation. Production of ovarian $\beta$ endorphin is confirmed by the fact that mRNA for proopiomelanocortin was found in the ovaries (Melner et al., 1986; Jin et al., 1988; Sanders et al., 1990). However, it is not possible to eliminate the possibility that the $\beta$-endorphin-like immunoreactivity measured may be from other sources. Lovegren et al. (1991) reported changes in ovarian content of $\beta$-endorphin at different times after injection with 20 iu eCG and 10 iu hCG $48 \mathrm{~h}$ later. If the $\beta$-endorphin-like immunoreactivity is expressed as per mg protein or per unit tissue wet mass, a significant decrease was observed after hCG treatment. The presence of $\beta$-endorphin in human follicular fluid at concentrations several times higher than those in plasma has been reported (Facchinetti et al., 1986; Kerdelhue et al., 1997). It has been suggested that the ovaries may contribute to the plasma concentrations of $\beta$-endorphin during the menstrual cycle of women (Comitini et al., 1989). As $\beta$-endorphin exerts an inhibitory action on ovulation, and prostaglandins and NO production are augmented during this process, the present study investigated whether these inflammatory agents diminish opioid peptide content of the ovary. The intrabursal administration of $\mathrm{NO}$ inhibitors did not affect the ovarian $\beta$-endorphin-like immunoreactivity, but treatment with prostaglandin synthesis inhibitors augmented it. These results indicate that prostaglandins exert a negative downregulation on $\beta$-endorphin-like immunoreactivity in the ovary during the ovulatory process. It is important to point out that neither indomethacin nor meloxicam treatment completely reversed $\beta$-endorphin-like immunoreactivity to values that were recorded before hCG treatment. Therefore, there must be another pathway independent of the prostaglandin-NO system that reduces ovarian $\beta$-endorphin content during ovulation. The administration of naltrexone to immature rats (28-30 days old) advanced the first ovulation in $55-75 \%$ of animals (Meijs-Roelofs and Kramer, 1989). These data indicate that endogenous peptides critically restrict $\mathrm{LH}$ secretion and may constitute a hypothalamic restraint on the onset of puberty. In addition, previous studies demonstrated that $\beta$-endorphin affects ovulation in the rat ovary (Faletti et al., 1995, 1997). All these data indicate that endogenous opioids may be modulating this physiological process, at least in part, by altering ovarian prostaglandin production. The function of ovarian opioid peptides is not known, but they presumably act in an autocrine or paracrine manner in the ovary. The ovulatory process comprises the period between the $\mathrm{LH}$ surge (or hCG injection) and follicular rupture. The ovarian NOS activity increases after the LH surge or the gonadotrophin stimulation, and the $\mathrm{NO}$ produced stimulates the synthesis of prostaglandins. In turn, the LH surge or hCG administration inhibits the production of $\beta$-endorphin, thus avoiding high amounts of this peptide and permitting an efficient induction of ovulation.

The authors thank Daniel E González and J. Fernandez Cueto for their technical assistance. This work has been supported by Grant PEI 0092/97 and BID 802-OC-AR-PICT 00353 from Consejo Nacional de Investigaciones Científicas y Técnicas (CONICET), PRE-032/99 from Programa Latinoamericano de Capacitación e Investigación en Reproducción Humana (PLACIRH).

\section{References}

Aleem FA, Omar RA and El Tabbakh GH (1986) Immunoreactive $\beta$ endorphin in human ovaries Fertility and Sterility 45 507-512

Bauminger S and Lidner HR (1975) Periovulatory changes in ovarian prostaglandins formation and their hormonal control in the rat Prostaglandins 9 737-751

Ben-Shlomo I, Kokia E, Jackson MJ, Adashi EY and Payne DW (1994) Interleukin-1 $\beta$ stimulates nitrite production in the rat ovary: evidence for heterologous cell-cell interaction and for insulin-mediated regulation of the inducible isoform of nitric oxide synthase Biology of Reproduction 51 310-318

Bonello N, McKie K, Jasper M, Andrew L, Ross N, Braybon E, Brännström $\mathbf{M}$ and Norman RJ (1996) Inhibition of nitric oxide: effects on interleukin-1 $\beta$-enhanced ovulation rate steroid hormones and ovarian leukocyte distribution at ovulation in the rat Biology of Reproduction $\mathbf{5 4}$ 436-445

Bredt DS and Snyder SH (1989) Nitric oxide mediates glutamate-linked enhancement of cGMP levels in the cerebellum Proceedings National Academy of Sciences USA 86 9030-9033

Bredt DS and Snyder SH (1990) Isolation of nitric oxide synthetase a calmodulin-requiring enzyme Proceedings National Academy of Sciences USA 87 682-685

Brown CG and Poyser NL (1984) Studies on ovarian prostaglandin production in relation to ovulation in rat Journal of Reproduction and Fertility 72 407-412

Burnett AL, Ricker DD, Chamnes SL, Maguire MP, Crone JK, Bredt DS, Snyder SH and Chang TSK (1995) Localization of nitric oxide synthase in the reproductive organs of the male rat Biology of Reproduction 52 $1-7$

Chen CL, Chang CC, Krieger DT and Bardin CW (1986) Expression and regulation of proopiomelanocortin-like gene in the ovary and placenta: comparison with the testis Endocrinology 118 2382-2389

Comitini G, Petraglia F, Facchinetti F, Monaco M, Volpe A and Genazzani AR (1989) Effect of oral contraceptives or dexamethasone on plasma beta-endorphin during the menstrual cycle Fertility and Sterility $\mathbf{5 1}$ 4650

Dong YL and Yallampalli C (1996) Interaction between nitric oxide and $\mathrm{PGE}_{2}$ pathways in pregnant rat uteri American Journal of Physiology 270 E471-E476

Drazen DL, Klein SL, Burnett AL, Wallach EE, Crone JK, Huang PL and Nelson RJ (1999) Reproductive function in female mice lacking the gene for endothelial nitric oxide synthase Nitric Oxide: Biology and Chemistry 3 366-374

Ellman C, Corbett JA, Misko TP, McDaniel M and Beckerman KP (1993) Nitric oxide mediates interleukin-1-induced cellular cytotoxicity in the rat ovary: a potential role for nitric oxide in the ovulatory process Journal of Clinical Investigation 92 3053-3056

Facchinetti F, Ruspa M, Turci A, Petraglia F, Segre A, Forabosco A and Genazzani AR (1986) Met-enkephalin enhances folliclestimulating hormone-dependent progesterone production from cultured 
granulosa cells Journal of Clinical Endocrinology and Metabolism 63 1222-1224

Faletti A, Bassi D, Gimeno AL and Gimeno MAF (1992) Effects of beta-endorphin on spontaneous uterine contractions prostaglandins production and ${ }^{45} \mathrm{Ca}^{2+}$ uptake in uterine strips from ovariectomized rats Prostaglandins, Leukotrienes and Essential Fatty Acids 47 29-33

Faletti A, Viggiano JM and Gimeno MAF (1995) Beta-endorphin inhibits prostaglandin synthesis in rat ovaries and blocks induced ovulation Prostaglandins 9 93-103

Faletti A, Jawerbaum A, Viggiano J and Gimeno MAF (1997) Naltrexone enhances ovulation and prostaglandin synthesis in the rat ovary Prostaglandins 54 665-675

Faletti A, Pérez-Martínez S, Perotti C and Gimeno MAF (1999a) Activity of ovarian nitric oxide synthase (NOS) during ovulatory process in the rat: relationship with prostaglandins (PGs) production Nitric Oxide: Biology and Chemistry 3 330-347

Faletti AG, Mastronardi CA, Lomniczi A, Seilicovich A, Gimeno M, McCann SM and Rettori V (1999b) $\beta$-endorphin blocks luteinizing hormonereleasing hormone release by inhibiting the nitricoxidergic pathway controlling its release Proceedings National Academy of Science USA 96 1722-1726

Farina M, Ribeiro ML, Ogando D, Gimeno M and Franchi A (2000) IL $1 \alpha$ augments prostaglandin synthesis in pregnant rat uteri by a nitric oxide mediated mechanism Prostaglandins, Leukotrienes and Essential Fatty Acids 62 243-247

Farina M, Ribeiro ML and Franchi A (2001) Nitric oxide synthase in pregnant rat uterus Reproduction 121 403-407

Galinelli A, Garuti G, Matteo ML, Genazzani AR and Facchinetti F (1995) Expression of proopiomelanocortin gene in human ovarian tissue Human Reproduction 10 1085-1089

Gregoraszczuk EL and Slomczynska M (1998) Beta-endorphin inhibition of progesterone secretion by porcine granulosa cells during follicle development Reproduction, Nutrition and Development $\mathbf{3 8}$ 227-234

Hamada H, Kishioka S, Yamoto $\mathbf{M}$ and Nakano $\mathbf{R}$ (1995) $\left[{ }^{3} \mathrm{H}\right]-$ naloxone binding sites in porcine ovarian follicles and corpora lutea during the ovarian cycle European Journal of Endocrinology 132 622-626

Jablonka-Shariff A and Olson LM (1997) Hormonal regulation of nitric oxide synthase and their cell-specific expression during follicular development in the rat ovary Endocrinology 138 460-468

Jablonka-Shariff A and Olson LM (1998) The role of nitric oxide in oocyte meiotic maturation and ovulation: meiotic abnormalities of endothelial nitric oxide synthase knock-out mouse oocyte Endocrinology 139 2944-2954

Jablonka-Shariff A, Ravi S, Beltos AN, Murphy LL and Olson LM (1999) Abnormal estrous cyclicity after disruption of endothelial and inducible nitric oxide synthase in mice Biology of Reproduction $\mathbf{6 1}$ $171-177$

Jin DF, Muffly KE, Okulicz WC and Kilpatrick DL (1988) Estrous cycle- and pregnancy-related differences in expression of the proenkephalin and proopiomelanocortin genes in the ovary and uterus Endocrinology 122 1466-1471

Kaminski T, Siawrys G, Bogacka I and Przala J (2000) The physiological role of beta-endorphin in porcine ovarian follicles Reproduction, Nutrition and Development 40 63-75

Kerdelhue B, Lenoir V, Kolm P, Seltman HJ, Jones HW, Jr and Jones GS (1997) ACTH, beta-endorphin, substance $P$, and corticotrophin releasing hormone in plasma and follicular fluid in hormonally stimulated menstrual cycles for in-vitro fertilization in the human Human Reproduction 12 231-235

Leadem CA and Kalra SP (1985) Reversal of beta-endorphin-induced blockade of ovulation and luteinizing hormone surge with prostaglandin $\mathrm{E}_{2}$ Endocrinology 117 684-689

Lim AT, Lolait S, Barlow JW, O WS, Zois I, Toh BH and Funder JW (1983) Immunoreactive $\beta$-endorphin in sheep ovary Nature 303 709-711

Lolait SJ, Autelitano DJ, Lim AT, Smith AI, Toh BH and Funder JW (1985)
Ovarian immunoreactive $\beta$-endorphin and estrous cycle in the rat Endocrinology 117 161-168

Lolait SJ, Autelitano DJ, Markwick AJ, Toh BH and Funder JW (1986) Co-expression of vasopressin with $\beta$-endorphin and dynorphin in individual cells from the ovaries of Brattleboro and Long-Evans rats: immunocytochemical studies Peptides 7 267-276

Lomniczi A, Mastronardi CA, Faletti AG, Seilicovich A, De Laurentiis A, McCann SM and Rettori V (2000) Inhibitory pathways and the inhibition of luteinizing hormone-releasing hormone release by alcohol Proceedings National Academy of Sciences USA 97 2337-2342

Lovegren ES, Zimniski SJ and Puett D (1991) Ovarian contents of immunoreactive $\beta$-endorphin and $\alpha-\mathrm{N}$-acetylated opioid peptides in rats Journal of Reproduction and Fertility 91 91-100

Meijs-Roelofs HM and Kramer P (1989) Advancement of first ovulation by the opioid antagonist naltrexone Biology of Reproduction $\mathbf{4 1}$ 842-847

Melner MH, Young SL, Czerwiec FS, Lyn D, Puett D, Roberts JL and Koss RD (1986) The regulation of granulosa cell proopiomelanocortin mRNA by androgens and gonadotropins Endocrinology 119 2082-2088

Mitsube K, Mikuni M, Matousek M and Brännström M (1999) Effects of a nitric oxide donor and nitric oxide synthase inhibitors on luteinizing hormone-induced ovulation in the ex-vivo perfused rat ovary Human Reproduction 14 2537-2543

Moncada S, Palmer RM and Higgs EA (1991) Nitric oxide: physiology, pathophysiology and pharmacology Pharmacology Reviews 43109 142

Nakamura Y, Kashida S, Nakata M, Takiguchi S, Yamagata Y, Takayama H, Sugino $\mathbf{N}$ and Kato $\mathbf{H}$ (1999) Changes in nitric oxide synthase activity in the ovary of gonadotropin treated rats: the role of nitric oxide during ovulation Endocrine Journal 46 529-538

Nandhra TS and Carson RJ (2000) $\beta$-endorphin inhibits the production of interleukin- 8 by human chorio-decidual cells in culture Molecular Human Reproduction 6 555-560

Olson LM, Jones-Burton CM and Jablonka-Shariff A (1996) Nitric oxide decreases estradiol synthesis of rat luteinized ovarian cells: possible role for nitric oxide in functional luteal regression Endocrinology 1373531 3539

Pollock JS, Forstermann U, Mitchell JA, Warner TD, Schmidt HH, Nakane $\mathbf{M}$ and Murad F (1991) Purification and characterization of particulate endothelium-derived relaxing factor synthase from cultured and native bovine aortic endothelial cells Proceedings National Academy of Sciences USA 8810 480-10 484

Salvemini D, Misko TP, Masferrer JL, Seibert K, Currie MG and Needleman P (1993) Nitric oxide activates cyclo-oxygenase enzymes Proceedings National Academy of Sciences USA 90 7240-7244

Sanders SL, Melner MH and Curry TE, Jr (1990) Cellular localization of ovarian proopiomelanocortin mRNA during follicular and luteal development in the rat Molecular Endocrinology 4 1311-1319

Shaha C, Margioris A, Liotta AS, Krieger DT and Bardin CW (1984) Demonstration of immunoreactive $\beta$-endorphin and $\gamma_{13}$-melanocytestimulating hormone-related peptides in the ovaries of neonatal cyclic and pregnant mice Endocrinology 115 378-384

Shukovski L and Tsafriri A (1994) The involvement of nitric oxide in the ovulatory process in the rat Endocrinology 135 2287-2290

Stuehr DJ, Cho HJ, Kwon NS, Weise MF and Nathan CF (1991) Purification and characterization of the cytokine inducible macrophage nitric oxide synthase an FAD- and FMN-containing flavoprotein Proceedings National Academy of Sciences USA 88 7773-7777

Suburu AM, Chaud M, Franchi AM, Polak JM and Gimeno MAF (1995) Distribution of neuronal and non-neuronal NADPH diaphorases and nitric oxide synthase in rat uterine horns under different hormonal conditions Biology of Reproduction $\mathbf{5 2}$ 631-637

Van Voorhis BJ, Dunn MS, Snyder GD and Weiner CP (1994) Nitric oxide: an autocrine regulator of human granulose-luteal cell steroidogenesis Endocrinology 135 1799-1806

Van Voorhis BJ, Moore K, Strijbos PJML, Nelson S, Baylis SA, Grzybicki D and Weiner CP (1995) Expression and localization of inducible and 
endothelial nitric oxide synthase in the rat ovary Journal of Clinical Investigation 96 2719-2726

Yamauchi J, Miyazaki T, Iwasaki S, Kishi I, Kuroshima M, Tei C and Yoshimura $\mathbf{Y}$ (1997) Effects of nitric oxide on ovulation and ovarian steroidogenesis and prostaglandin production in the rabbit Endocrinology 138 3630-3637

Zackrisson U, Mikuni M, Wallin A, Delbro D, Hedin L and Brännström M (1996) Cell-specific localization of nitric oxide synthases (NOS) in the rat ovary during follicular development ovulation and luteal formation Human Reproduction 11 2667-2673

Received 18 September 2002.

First decision 20 November 2002.

Revised manuscript received 11 December 2002.

Accepted 20 December 2002. 